\title{
OPTIMALISASI EKSTRAKSI DAN UJI METABOLIT SEKUNDER TUMBUHAN LIBO (FICUS VARIEGATE BLUME)
}

\author{
Lizma Febrina*, Rolan Rusli, Fairul Muflihah \\ Laboratorium Penelitian dan Pengembangan FARMAKA TROPIS Fakultas Farmasi \\ Universitas Mulawarman, Samarinda, Kalimantan Timur \\ *email:lizma@farmasi.unmul.ac.id
}

\begin{abstract}
Libo leaves (Ficus variegate Blume) is never eaten by caterpillars. This is indicated that libo leaves has a good secondary metabolites. This research was conducted on optimization of extraction techniques and test of secondary metabolites of leaves Libo. The optimization was done by changing variables viz. method of extraction, variation of amount of solvent, and duration of extraction. The effectiveness of extraction was seen from \% of yield. Method of extraction was using maceration and soxhlet. Methanol was used as solvent with various 1:10, 1: 20, and 1:30. Durations of extraction were 1, 2, 3, 4, and 5 days for maceration and 1,2, 3, 4, and 5 cycles for soxhlet. The results show that the best method for extraction libo leaves was soxhlet with 34\% of yield, solvent ratio 1:30, and 5 cycle of duration of extraction. The secondary metabolites of libo leaves were phenols, flavonoids and alkaloids.
\end{abstract}

Keywords: Optimization of extraction, Libo leaves (Ficus variegate Blume), Secondary Metabolite

\begin{abstract}
ABSTRAK
Tumbuhan Libo (Ficus variegate Blume) merupakan salah satu tumbuhan liar, dan bagian daunnya tidak pernah dimakan oleh ulat. Pada Tahap ini dilakukan optimalisasi teknik ekstraksi dan menguji metabolit sekunder daun libo. Optimalisasi dilakukan dengan mengubah berbagai variabel yaitu metode ekstraksi, variasi jumlah pelarut, dan lamanya waktu ekstraksi. Efektivitas ekstraksi dilihat dari \%rendemen yang dihasilkan. Metode yang digunakan adalah maserasi dan soxhlet, sedangkan pelarut yang digunakan adalah metanol dengan variasi jumlah pelarut $1: 10,1: 20,1: 30$ serta variasi waktu ekstraksi $(1,2,3$ 4 dan 5 hari untuk maserasi dan 1,2,3,4 dan 5 siklus untuk metode soxhlet). Hasil yang didapat dari penelitian ini adalah metode terbaik untuk ekstraksi daun libo adalah metode soxhlet dengan $\%$ rendemen 34,00 dengan perbandingan pelarut 1:30 dengan lama ekstraksi sebanyak 5 siklus. Dari pengujian metabolit sekunder diketahui daun Libo ini mengandung fenol, flavonoid dan alkaloid.
\end{abstract}

Kata Kunci : Optimalisasi Ekstraksi, Daun Libo (Ficus variegate Blume), Metabolit Sekunder 


\section{PENDAHULUAN}

Libo diklasifikasikan ke dalam kerajaan Plantae (tumbuhan). Tumbuhan ini merupakan salah satu tumbuhan liar, memiliki tinggi hingga 10 meter, batang bulat, bercabang, daun tersebar,memiliki bentuk bulat telur, ujung runcing, pertulangan menyirip, dan berwarna hijau. Tumbuhan ini belum banyak diketahui manfaatnya, dikarenakan penelitian tentang tumbuhan ini sangat jarang. Tetapi faktanya, tumbuhan ini memiliki buah dan daun yang tidak dimakan oleh hama atau serangga, sehingga tumbuhan tersebut diduga memiliki sifat toksik pada buah dan daunnya. Hal ini sangat menarik untuk diuji metabolit sekunder dan pemanfaatan aktivitas biologisnya.

Metabolit sekunder yang diproduksi oleh berbagai organisme, termasuk daun libo memang tidak memiliki peran yang cukup signifikan terhadap keberlangsungan hidup dari organisme penghasilnya. Namun, sangat dibutuhkan oleh keperluan hidup manusia, baik digunakan untuk keperluan industri maupun untuk bahan obat-obatan. Hal ini dikarenakan metabolit sekunder tersebut memiliki berbagai aktivitas biologi antara lain antikanker, antibakteri, antioksidan dan antifungi.

Isolasi senyawa metabolit sekunder dari suatu tanaman dikenal dengan nama ekstraksi. Ekstraksi adalah proses penarikan komponen/zat aktif dari suatu campuran padatan dan/atau cairan dengan menggunakan pelarut tertentu. Proses ini merupakan langkah awal yang penting dalam penelitian tanaman obat, karena preparasi ekstrak kasar tanaman merupakan titik awal untuk isolasi dan pemurnian komponen kimia yang terdapat pada tanaman [1]. Berdasarkan fase yang terlibat, terdapat 2 jenis ekstraksi, yaitu ekstraksi cair-cair dan ekstraksi padat-cair. Proses ekstraksi padat-cair sangat dipengaruhi oleh banyak faktor, di antaranya waktu ekstraksi, suhu yang digunakan, pengadukan, dan banyaknya pelarut yang digunakan [2]. Ekstraksi padat cair secara umum terdiri dari maserasi, refluktasi, sokhletasi, dan perkolasi. Metode yang digunakan tergantung dengan jenis senyawa yang ingin kita cari. Jika senyawa yang ingin dicari rentan terhadap pemanasan maka metode maserasi dan perkolasi yang kita pilih, jika tahan terhadap pemanasan maka metoda refluktasi dan soxhletasi yang digunakan [3].

Optimalisasi ekstraksi bertujuan mencari atau menemukan nilai peubah dalam proses yang menghasilkan nilai terbaik dari syarat-syarat kondisi yang digunakan. Penyelesaian optimalisasi terfokus pada pemilihan secara tepat dan hemat biaya di antara keseluruhan dan proses metode kuantitatif yang efisien. Termasuk didalamnya komputer serta perangkat lunak program komputasi. Dalam penelitian ini digunakan nilai peubah variasi jumlah pelarut yang digunakan serta waktu ekstraksi guna menghasilkan rendemen terbanyak.

\section{METODE PENELITIAN}

\section{Bahan}

Daun Libo, metanol p.a, asam klorida pekat, serbuk magnesium, besi (III) klorida, asam asetat glasial dan asam sulfat pekat.

\section{Peralatan}

Seperangkat alat soxhlet, seperangkat alat maserasi, seperangkat alat gelas, desikator, waterbath, rotary evaporator, timbangan analitik.

\section{Prosedur}

\section{Penyiapan Sampel}

Daun Libo yang diambil adalah bagian daun yang masih utuh, hijau, segar, kemudian dikumpulkan dan dipisahkan dengan pengotor lainnya seperti tanah, bagian bukan daun atau bagian tanaman yang rusak. Setelah itu 
sampel ditimbang kembali, selanjutnya sampel dicuci bersih dengan air mengalir untuk menghilangkan dari kotoran yang melekat pada daun. Dipotong kecil-kecil sesuai derajat yang diinginkan. Kemudian dikeringkan diudara terbuka terlindung dari sinar matahari.

\section{Ekstraksi Sampel}

Simplisia kering yang sudah dihaluskan, kemudian diekstraksi menggunakan dua metode, yaitu cara panas dan cara dingin. Maserasi mewakili cara dingin sementara soxhlet mewakili cara panas.

a. Metode Ekstraksi Maserasi

Sebanyak 10 gram serbuk daun libo dibungkus menggunakan kertas saring, kemudian dimasukkan kedalam botol gelap, tambahkan pelarut metanol dengan variasi pelarut 1:10, 1:20, dan 1:30. Rendam selama 1 hari sambil sesekali diaduk, kemudian bungkus serbuk daun libo tersebut diambil. Filtrat yang diperoleh kemudian dipekatkan dengan menggunakan rotary evaporator, selanjutnya didapatkan ekstrak kental. Ulangi langkah diatas dengan mengganti waktu maserasi selama 2,3,4 dan 5 hari.

b. Metode Ekstraksi Soxhlet

Dipasang alat soxhlet, kemudian masukkan serbuk daun libo yang telah dibungkus dengan kertas saring ke dalam alat soxhlet, masukkan pelarut metanol dengan perbandingan 1: 10, 1: 20 dan 1:30. Lakukan proses soxhletasi pada suhu $70^{\circ} \mathrm{C}$. Waktu ekstraksi dilakukan hingga pelarut pada sifon penuh, atau selanjutnya disebut sebagai 1 siklus. Ekstrak cair yang diperoleh kemudian dipekatkan dengan menggunakan rotary evaporator Langkah diatas diulangi dengan mengganti waktu ekstraksi selama 2,3,4 dan 5 siklus.

Dihitung hasil rendemen ekstrak metanol daun libo dengan rumus sebagai berikut :

$\%$ Rendemen $=\frac{\text { jumlah berat sampel hasil }}{\text { jumlah berat sampel awal }} \times 100 \%$

J. Trop. Pharm. Chem. 2015. Vol 3. No. 2 p-ISSN: 2087-7099; e-ISSN: 2407-6090

\section{Uji Metabolit Sekunder}

\section{a. Uji Alkaloid}

Sebanyak $2 \mathrm{~mL}$ ekstrak diuapkan di atas cawan porselin. Residu yang dihasilkan kemudian dilarutkan dengan 5 $\mathrm{mL} \mathrm{HCl} 2 \mathrm{M}$. Larutan yang diperoleh dibagi ke dalam 3 tabung reaksi. Tabung pertama berfungsi sebagai blanko, ditambahkan dengan 3 tetes $\mathrm{HCl} 2 \mathrm{M}$. Tabung kedua ditambahkan 3 tetes pereaksi Dragendorff dan tabung ketiga ditambahkan 3 tetes pereaksi Mayer. Pada pereaksi Dragendorff akan terbentuk endapan berwarna jingga sedangkan pereaksi Mayer akan terbentuk endapan kuning yang menandakan positif adanya alkaloid [4].

\section{b. Uji Fenol}

Ekstrak sampel sebanyak $1 \mathrm{ml}$ dimasukkan ke dalam tabung reaksi untuk dilakukan pengujian fenolik dengan cara ekstrak ditambahkan pereaksi $\mathrm{FeCl}_{3} 1 \%$, jika terjadi warna hitam menunjukkan adanya senyawa fenolik.

\section{c. Uji Flavonoid}

Sebanyak $2 \mathrm{~mL}$ ekstrak ditambahkan dengan air panas secukupnya, kemudian dididihkan selama 5 menit lalu disaring. Filtrat sebanyak 5 $\mathrm{mL}$ ditambahkan 0,05 mg serbuk $\mathrm{Mg}$ dan $1 \mathrm{~mL} \mathrm{HCl}$ pekat, kemudian dikocok kuatkuat. Uji positif ditunjukkan dengan terbentuknya warna merah, kuning atau jingga [2].

\section{d. Uji Tanin}

Sebanyak 1 mL ekstrak ditambahkan dengan beberapa tetes larutan besi(III)klorida 10\%. Jika terjadi warna biru tua atau hitam kehijauan menunjukkan adanya tannin [5].

\section{e. Uji Steroid}

Sebanyak $2 \mathrm{~mL}$ ekstrak ditambahkan $\mathrm{CH}_{3} \mathrm{COOH}$ glasial sebanyak 10 tetes dan $\mathrm{H}_{2} \mathrm{SO}_{4}$ pekat sebanyak 2 
tetes. Larutan dikocok perlahan dan dibiarkan selama beberapa menit. Adanya steroid ditunjukan oleh warna biru atau hijau, sedangkan triterpenoid memberikan warna merah atau ungu [2].

\section{f. Uji Saponin}

Sebanyak 2-3 $\mathrm{mL}$ ekstrak dimasukkan ke dalam tabung reaksi, kemudian ditambahkan $10 \mathrm{~mL}$ air panas lalu didinginkan, kemudian dikocok kuatkuat selama 10 detik lalu ditambahkan 1 tetes $\mathrm{HCl} 2 \mathrm{~N}$. Uji positif ditunjukkan dengan terbentuknya buih yang stabil setinggi $1-10 \mathrm{~cm}$ selama tidak kurang dari 10 menit [6].

\section{HASIL DAN PEMBAHASAN}

\section{Ekstraksi Daun Libo}

Ekstraksi padat-cair yang dilakukan pada daun libo menggunakan cara panas dan cara dingin. Meserasi mewakili cara dingin sedangkan soxhlet mewakili cara panas. Alasan pemilihan maserari dan soxhlet dikarenakan mempunyai banyak keuntungan dibandingkan metode yang lainnya. Keuntungan utama metode ekstraksi maserasi adalah prosedur dan peralatan yang digunakan sederhana, metode ini tidak dipanaskan sehingga bahan alam yang dikandungnya tidak terurai. Ekstraksi dingin memungkinkan banyak senyawa terekstraksi, meskipun beberapa senyawa memiliki kelarutan terbatas dalam pelarut ekstraksi pada suhu kamar, sedangkan metode ekstraksi cara panas (soxhlet) memiliki keuntungan berupa pelarut yang digunakan lebih sedikit (efisien bahan), waktu yang digunakan lebih cepat, sampel yang diekstraksi secara sempurna karena dilakukan berulang-ulang. Selain itu aktivitas biologis tidak hilang saat dipanaskan [3].
Pelarut yang digunakan untuk mengekstraksi pada penelitian ini adalah metanol, dikarenakan sifatnya yang mampu melarutkan hampir semua zat, baik yang bersifat polar maupun non polar. Aspek yang diamati pada penelitian ini adalah rendemen yang dihasilkan dari pengubahan variabel jumlah pelarut dan waktu ekstraksi. Besar kecilnya rendemen menunjukkan keefektifan proses ekstraksi.

Terlihat bahwa perbandingan sampel:jumlah pelarut yang menghasilkan rendemen terbanyak adalah pada perbandingan 1:30. Semakin banyak jumlah pelarut yang digunakan pada metode ekstraksi maka hasil yang didapatkan semakin banyak pula. Hal ini dikarenakan distribusi partikel dalam pelarut semakin menyebar, sehingga memperluas permukaan kontak. Pada Tabel 1 juga memperlihatkan semakin lama waktu ekstraksi hasil yang didapat semakin banyak.

Pada gambar 2 terlihat bahwa \% rendemen yang dihasilkan baik pada perbandingan 1:10, 1: 20 dan 1: 30 pada hari ke 5 tidak jauh berbeda dengan hari ke 4. Hal ini dikarenakan pada hari ke 4 telah terjadinya keseimbangan antara bahan yang diekstraksi pada bagian sel yang rusak dengan yang ada pada pelarut telah tercapai, sehingga proses difusi telah selesai. Secara teoritis tidak memungkinnya terjadinya ekstrasi absolut.

Dari tabel 2, memperlihatkan kecenderungan yang sama dengan hasil ekstraksi menggunakan metode maserasi bahwa perbandingan sampel:jumlah pelarut yang menghasilkan rendemen terbanyak adalah pada perbandingan 1:30 dan semakin lama waktu ekstraksi menghasilkan rendemen yang semakin banyak pula. 
Tabel 1. Hasil Rendemen Ekstrak Hasil Maserasi

\begin{tabular}{cccc}
\hline $\begin{array}{c}\text { Waktu Ekstraksi } \\
\text { (Hari) }\end{array}$ & $\begin{array}{c}\text { Perbandingan } \\
\text { S:P }\end{array}$ & $\begin{array}{c}\text { Berat Ekstrak } \\
\text { (gram) }\end{array}$ & \% Rendemen \\
\hline 1 & $1: 10$ & 0,25 & 2,49 \\
& $1: 20$ & 0,36 & 3,59 \\
& $1: 30$ & 1,50 & 14,99 \\
2 & $1: 10$ & 0,57 & 5,69 \\
& $1: 20$ & 0,62 & 6,19 \\
3 & $1: 30$ & 0,67 & 16,68 \\
& $1: 10$ & 0,78 & 7,70 \\
& $1: 20$ & 0,79 & 7,80 \\
4 & $1: 30$ & 1,80 & 17,77 \\
& $1: 10$ & 1,02 & 10,18 \\
5 & $1: 20$ & 1,30 & 12,98 \\
& $1: 30$ & 2,32 & 23,14 \\
& $1: 10$ & 1,05 & 10,47 \\
& $1: 20$ & 1,30 & 12,98 \\
& $1: 30$ & 2,40 & 23,94 \\
\hline
\end{tabular}

Keterangan : S : P adalah perbandingan antara jumlah sampel dengan volume pelarut

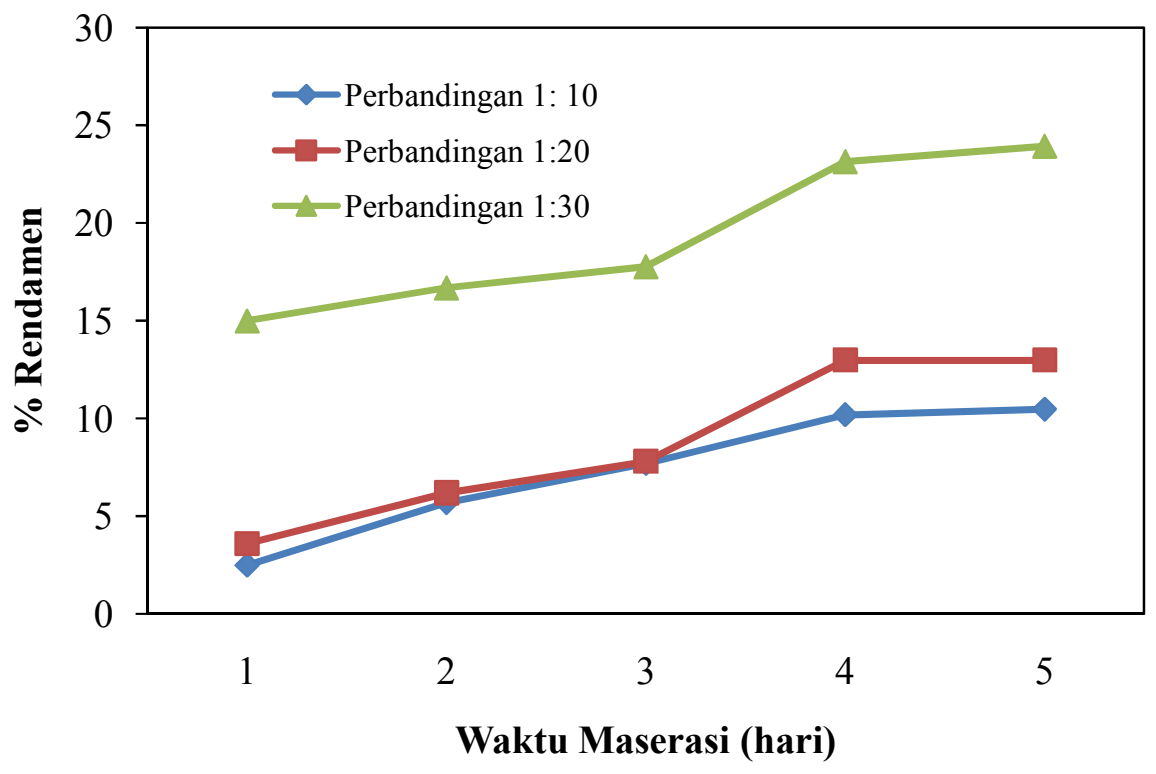

Gambar 1. Hubungan Antara Waktu Maserasi dengan \% Rendemen Pada Berbagai Perbandingan Jumlah Pelarut 
Tabel 2. Hasil Rendemen Ekstrak Hasil Soxhlet

\begin{tabular}{cccc}
\hline $\begin{array}{c}\text { Waktu Ekstraksi } \\
\text { (Siklus) }\end{array}$ & $\begin{array}{c}\text { Perbandingan } \\
\text { S:P }\end{array}$ & $\begin{array}{c}\text { Berat Ekstrak } \\
\text { (gram) }\end{array}$ & \% Rendemen \\
\hline 1 & $1: 10$ & 0,25 & 2,57 \\
& $1: 20$ & 0,44 & 4,44 \\
& $1: 30$ & 0,57 & 5,70 \\
2 & $1: 10$ & 0,64 & 6,38 \\
& $1: 20$ & 0,72 & 7,12 \\
& $1: 30$ & 0,83 & 8,29 \\
3 & $1: 10$ & 1.32 & 12,95 \\
& $1: 20$ & 1,87 & 18,35 \\
4 & $1: 30$ & 2,45 & 24,04 \\
& $1: 10$ & 2,00 & 19,74 \\
& $1: 20$ & 2,05 & 20,24 \\
5 & $1: 30$ & 3,33 & 32,87 \\
& $1: 10$ & 2,78 & 27,80 \\
& $1: 20$ & 2,91 & 29,09 \\
& $1: 30$ & 3,40 & 34,00 \\
\hline
\end{tabular}

Keterangan : S : P adalah perbandingan antara jumlah sampel dengan volume pelarut

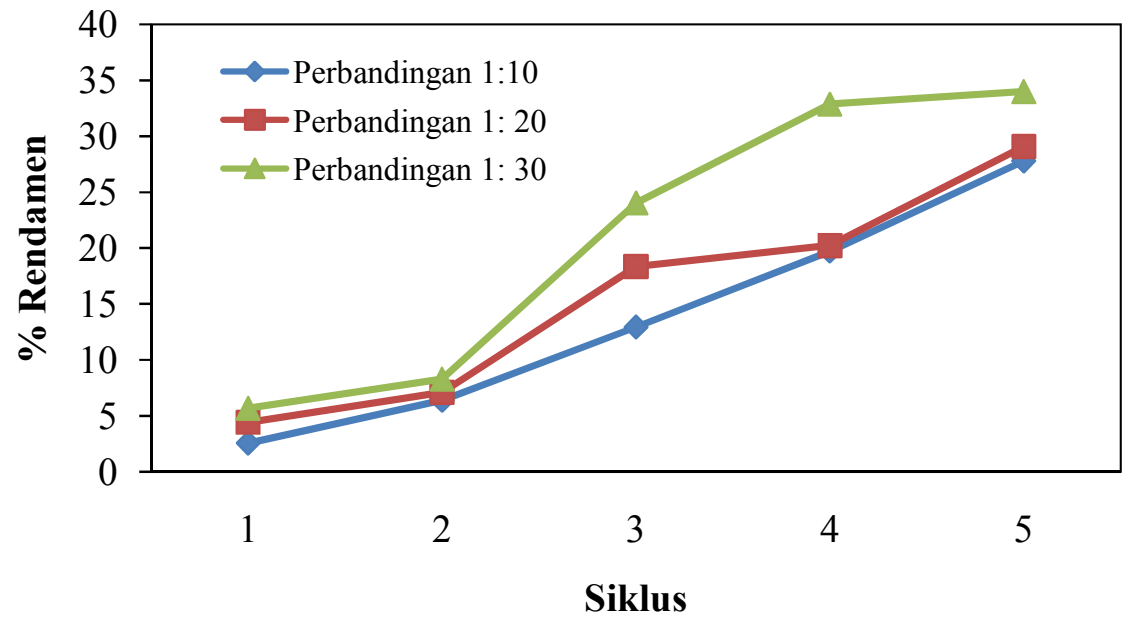

Gambar 2. Hubungan Antara Waktu Soxhlet dengan \% Rendemen Pada Berbagai Perbandingan Jumlah Pelarut

Berdasarkan data diatas dapat terlihat bahwa \% rendemen ekstrak daun libo terbanyak dihasilkan dengan perbandingan pelarut 1:30 dan hasil $\%$ rendemen terbanyak dihasilkan melalui metode soxhlet dibandingkan dengan metode maserasi. Hal ini dikarenakan metode ekstraksi soxhlet selalu menggunakan pelarut yang selalu baru yang umumnya dilakukan dengan alat khusus sehingga terjadi ekstraksi kontinu dengan jumlah pelarut yang relatif konstan dengan adanya pendingin balik. Sehingga pelarut yang digunakan akan mengalami sirkulasi dibandingkan dengan cara maserasi. 
Uji Metabolit Sekunder

Hasil metabolit sekunder menunjukan bahwa ekstrak metanol daun libo memiliki kandungan senyawa metabolit sekunder berupa fenol, flavonoid dan alkaloid. Tabel 3 menunjukan hasil metabolit sekunder terhadap ekstrak metanol daun libo.

Tabel 3. Hasil Uji Metabolit Sekunder Daun Libo

\begin{tabular}{|c|c|c|}
\hline No & Uji & Hasil \\
\hline 1 & Steroid & - \\
\hline 2 & Fenol & + \\
\hline 3 & Flavanoid & + \\
\hline 4 & Tanin & - \\
\hline 5 & Saponin & - \\
\hline 6 & Alkaloid a. Dragendoff & + \\
\hline & b. Mayer & + \\
\hline
\end{tabular}

Keterangan : (-) Tidak Terdeteksi (+) Senyawa Terdeteksi

\begin{abstract}
Alkaloid
Alkaloid yang diuji dengan menggunakan pereaksi Dragendorff akan menghasilkan endapan berwarna jingga, sedangkan dengan pereaksi Mayer akan menghasilkan endapan berwarna putih kekuningan, penambahan asam klorida bertujuan untuk mengekstrak alkaloid yang bersifat basa dengan menggunakan larutan asam [2-4]. Hasil uji metabolit sekunder menunjukan adanya endapan, yang berarti bahwa ekstrak daun libo mengandung senyawa alkaloid.
\end{abstract}

\section{Flavonoid}

Flavonoid dapat diuji keberadaannya menggunakan $\mathrm{Mg}$ dan $\mathrm{HCl}$ pekat. Senyawa flavonoid dapat menghasilkan warna merah, kuning atau jingga ketika tereduksi dengan $\mathrm{Mg}$ dan $\mathrm{HCl}$ [2]. Hasil menunjukan ekstrak metanol daun libo berwarna kuning dan positif terdapat flavonoid. Beragam warna yang dihasilkan ketika pengujian, dipengaruhi oleh pelarut dan prosedur yang digunakan [7].

\section{Tanin}

Identifikasi terhadap senyawa tanin dilakukan melalui penambahan $\mathrm{FeCl}_{3}$. Senyawa tanin adalah senyawa yang bersifat polar karena adanya gugus $\mathrm{OH}$, ketika ditambahkan $\mathrm{FeCl}_{3} \quad 10 \%$ akan terjadi perbahan warna seperti biru tua atau hijau kehitaman yang menandakan adanya senyawa tannin [5]. Tanin terhidrolisis akan menunjukan warna biru kehitaman sedangkan tanin terkondensasi akan menunjukan warna hijau kehitaman ketika penambahan $\mathrm{FeCl}_{3}$. Dari hasil metabolit sekunder pada ekstrak metanol daun libo, diperoleh hasil warna kuning kehijauan yang menandakan tidak mengandung senyawa tanin.

\section{Steroid}

Pengujian steroid dalam $\mathrm{CH}_{3} \mathrm{COOH}$ glasial dengan $\mathrm{H}_{2} \mathrm{SO}_{4}$ pekat didasarkan pada kemampuan senyawa steroid dalam membentuk cincin merah kecoklatan. Hasil uji metabolit sekunder menunjukan ekstrak metanol daun libo tidak terbentuk cincin yang menandakan bahwa tidak terdapat steroid pada ekstrak daun libo.

\section{Saponin}

Saponin merupakan senyawa aktif permukaan yang mudah terdeteksi melalui kemampuannya dalam membentuk busa. Komponen ikatan glikosida yang terdapat didalam saponin menyebabkan senyawa ini cenderung bersifat polar [2, 7]. Keberadaan saponin positif jika ekstrak yang diuji membentuk 
busa setinggi $1-10 \mathrm{~cm}$ dengan selang waktu \pm 10 menit [6]. Berdasarkan hasil skrining fitokimia menunjukan ekstrak metanol daun libo tidak terdapat saponin karena tidak membentuk busa.

\section{KESIMPULAN}

Pada penelitian ini didapatkan kesimpulan bahwa kondisi optimal pada ekstraksi daun libo adalah menggunakan metode soxhlet dengan perbandingan variasi pelarut 1: 30 dan semakin lama waktu ekstraksi dihasilkan \%rendemen yang semakin banyak pula.

\section{DAFTAR PUSTAKA}

1. Mandal.V, Yogesh M, Hemalatha., 2007. Microwave Assisted Extraction- An Innovative and Promising Extraction Tool for Medicinal Plant Research. Pharmacognosy Rev1:7-18.
2. Harborne, J.B., 1996. Metode Fitokimia. Terjemahan: Padmawinata, $\mathrm{K}$ dan Soediro, I. Institut Teknologi Bandung:Bandung.

3. Heinrich,Michael.,et al.,2004. Fundamental of Pharmacognosy and Phytotherapi. Hungary: Elsevier

4. Farsnworth, N. R. 1966. Biological and Phytochemical Screening of Plant. Journal of Pharmaceutical Sciences. 55: 59.

5. Jones, W.P., Kinghorn, A.D., 2006. Extraction of Plant Secondary Metabolites. In: Sharker, S.D. Latif Z., Gray A.L, eds. Natural Product Isolation. 2nd edition. Humana Press: New Jersey.

6. Depkes RI., 1995. Farmakope Indonesia. Departemen Kesehatan Republik Indonesia:Jakarta.

7. Sangi, M., Runtuwene, M.R.J., Simbala, H.E.I. and Makang, V.M.A. 2008. Analisis Fitokimia Tumbuhan Obat di Kabupaten Minahasa Utara. Chemistry Progress. 1:47-53. 